\title{
.eu Regulations under Brexit
}

\author{
Touko Johannes Sinisalo \\ Department of Law, \\ School of Business and Governance, \\ Tallinn University of Technology \\ Akadeemia tee 3 , \\ Tallinn 12618, Estonia \\ E-mail: tosini@taltech.ee
}

Abstract: On 28 March 2018, the European Commission published a press release stating that there is a plan to revoke all eu domains owned by the United Kingdom's individuals and entities due to Britain's exit from the European Union. The article highlights issues related to the process of the UK leaving the EU, gives examples from other fields of the Union law and the national law of the Member States which have experienced similar situations and also points out the fundamental rights that the Commission needs to comply with. The basics of domain names are also partially covered to inform the reader about what domain names are based on and of existing regulations in the field.

Keywords: Brexit, domain name, eu domain, European Union, top-level domain

\section{Introduction}

The research highlights problems related to domain names regulations, specifically the nature of problems that might arise when the United Kingdom leaves the European Union. An additional focus area is intellectual property rights which are granted usually by the national governments or international organizations. Intellectual property rights are crucial to the performance of a business while they are beneficial to all economic sectors and they should be protected through bilateral and multilateral agreements internationally (NymanMetcalf et al., 2014). The research also seeks to define areas regulated by similar 
norms and standards that are based on domain names. There are some general principles and those are also highlighted against international differences: what kind of systems exist and how domain names could be seen in the sphere of other intellectual property rights. Intellectual property rights are almost an inseparable part of domain name policies.

Inside the European Union, many systems are harmonized and, for example, there are EU trademarks (Zirnstein, 2005). Also, entities established in the EU have the capacity to register also national trademarks from another Member States without any unnecessary restrictions (Dobrin \& Chochia, 2016, pp. 31-34). It should be noted that within the sphere of domain names there is no imposed standardization and especially with national domain names, states usually define their own policy. There are certain common principles and cooperation, although generally registries are not forced to follow any of them.

The research also highlights the technology related to domain names and its development and aims to give readers some basic knowledge to understand what are built in the features of domain names. Evolution of domain names has had a strong impact on how they are existing today and for that reason the research also reveals the parties connected to the beginnings of domain names. The sphere of domain names has also been influenced by politics, with a variety of influencing factors. Although domain names and the internet have existed for a considerably long time, almost all connections to governmental agencies have been severed only a few years ago. It clearly demonstrates that we need to be constantly vigilant when changes are made to the policy and, as some experts have argued, it might be a mistake to give operation of the foundations of the internet to just one nonprofit organization. At the beginning of this millennium, there were discussions about the future of domain names and whether it would be a better idea to transfer control to an international organization.

Overall, problems which exist are not insurmountable and domain names regulations and policies are sufficiently defined. Also, international collaboration gives domain names remarkable transparency and reliability which all partiesregistry, holder, etc. — could rely on. 


\section{Background}

\subsection{What is a domain name?}

Domain names are used for identifying servers on the internet. Servers use Internet Protocol (IP) addresses, which are a series of number (e.g., 193.40.254.28). However, it is difficult to remember long series of numbers and due to that domain names were created to identify servers on the internet rather than just using IP addresses. For common users, domain names are a way to access websites or part of an email address as a server where the email is heading. A domain name could be tehnically any combination of letters with the maximum of 63 charters (Mockapetris, 1987).

There are separate levels of domain names and they have separate names to distinguish between different levels:

- $\quad$ Top-level domain name (TLD, e.g., .eu and .net)

- $\quad$ Second-level domain name (SLD, e.g., eurid.eu)

- Third-level domain name, better known as subdomain (e.g., trust.eurid.eu and www.iis.se)

The division into the groups is not always straightforward and there are certain practical exceptions, although in general all domain names could be fitted to this categorization. For example, some TLDs take registrations under SLDs which could be intended for a special group of registrants, such as companies (e.g., .co. uk), and those are usually considered TLDs for practical reasons: there could be separate WHOIS data, etc. and they behave as independent TLDs.

\subsection{History}

The evolution of domain names began in the era of Advanced Research Projects Agency Network (ARPANET) (Zimmermann \& Emspak, 2017). Before the development of a centralized system, every computer had its own separate host file which granted access to the server to connect others (a sort of telephone dictionary for computers) (Walker, 2000). As the number of servers increased and managing the system became difficult, in 1983 the system was changed and became based on centralized (root) name servers (Stewart, 2000). After that moment, the system became very similar to how we know it today. The development of ARPANET began under Defense Advanced Research Projects Agency (DARPA), which is an agency of the United States Department of Defense (DARPA, n.d.). In 1988, the maintenance of root servers was transferred 
from DARPA to the Internet Assigned Numbers Authority (IANA), who take responsibility related to technical aspects (Snyder et al., 2016). In 1998, the Internet Corporation for Assigned Names and Numbers (ICANN) was founded and the ownership of IANA was partially transferred to the newly established organization. In 2016, all previously existing connections to the United States government were eliminated and domain names became technically independent from any specific government (Finley, 2016). Because DARPA has been part of the development, the US government, for example, has a .gov domain which is exceptional in the sphere of domain names (there were not many of such top-level domains (TLDs) before the launch of new generic top-level domains (gTLDs)) (ICANNWiki, n.d., c).

\subsection{Division into categories}

Domain names could be divided into many types of categories and the most common division is general top-level domains (gTLD) and country code toplevel domain names (ccTLD). gTLDs are not tied to a country and they are, as the name suggests, used as general domain names (York, 2014). For example, .com is a gTLD widely used by companies ('com' refers to company). ccTLDs are tied to a state and the state then has control over them (i.e. jurisdiction to regulate). There are also countries in which legislation does not exist, for example, university control TLDs and its policy (Myles, 2014). ccTLDs are popular in countries where they are meant to be used although some exceptions exist (e.g., domain hacks: goo.gl) (Hover, 2017). For example, .uk and .se are clear ccTLDs, whereas .eu is perceived as a ccTLD but could also be also a geographic TLD (such as .stockholm) (ICANNWiki, n.d., d).

There are also special domain names which kind of fall into both categories: for example, the .co TLD is technically completely ccTLD, but it has been marketed as gccTLD (Slegg, 2013). In general, it could be noticed that ISO 3166-1 (the standard laid down by the International Organization for Standardization) defines what domains could be categorized as ccTLDs and all other domains, not country-based domains, are mostly gTLDs. gTLDs are mostly divided into historical gTLDs (.com, .mil, etc.) and new gTLDs. gTLDs could be also divided into restricted normal gTLDs (.org), sponsored gTLDs (.aero), geographic gTLDs (.helsinki) and brand gTLD (.nokia) (Nokia, n.d.). 


\subsection{DNS}

If a SLD owner wants to point a domain name to a server it requires name servers which reply to user requests. There should be at least two name servers with the domain name because if one name server is not functioning, the other could handle requests (IANA requirement) (IANA, n.d., p. 13). There may also be more name servers and nowadays some service providers also offer Anycast (network addressing and routing methodology), which allows shorter request times (the nearest location is used to handle the request) (Jafferali, 2016). Name servers usually use SLD such as "ns1.eurid.eu", also IP addresses could be used (if domain name servers are under registered TLD then IP addresses are also added to the registry) (EURid, n.d., a). It is possible to have a domain name without name servers, although some TLDs require them (for example, before the new Information Society Code (2014) (since January 2018 Act on Electronic Communications Services), the .fi domain required two functioning name servers) (Domain Name Act, 2006).

\subsection{WHOIS}

WHOIS is a query and response protocol which enables users to send queries and ask registered details from the registry database. It is used mostly with domain names and IP address blocks. To operate a TLD there the registry usually requires a service provider take care of it (e.g., Afilias). The registry could contain various types of information (e.g., name servers, holder information, etc.). There are different kinds of policies about what type of information is displayed at WHOIS from the registry (the TLD owner regulates the area) (EURid, n.d., d). For example, the de registry only provides registrar (the organization which keeps records made in a registry, e.g., Enom) data in public WHOIS and under special circumstances, the registrant (SLD holder/owner) data will be disclosed to a specific third party based on, e.g., trademark claims (DENIC, 2016). A recent discussion related to WHOIS concerns how General Data Protection Regulation (GDPR) should be interpreted and whether registrars and registries are allowed to display publicly European Union based registrants' data (ICANN, 2018a). The practice has been that only necessary data should be collected and publicly displayed data should be restricted especially when private individuals are involved (if the owner is a private person) (ICANN v. EPAG GmbH [2018] ). 


\section{Figure 1. IIS.se public WHOIS data}

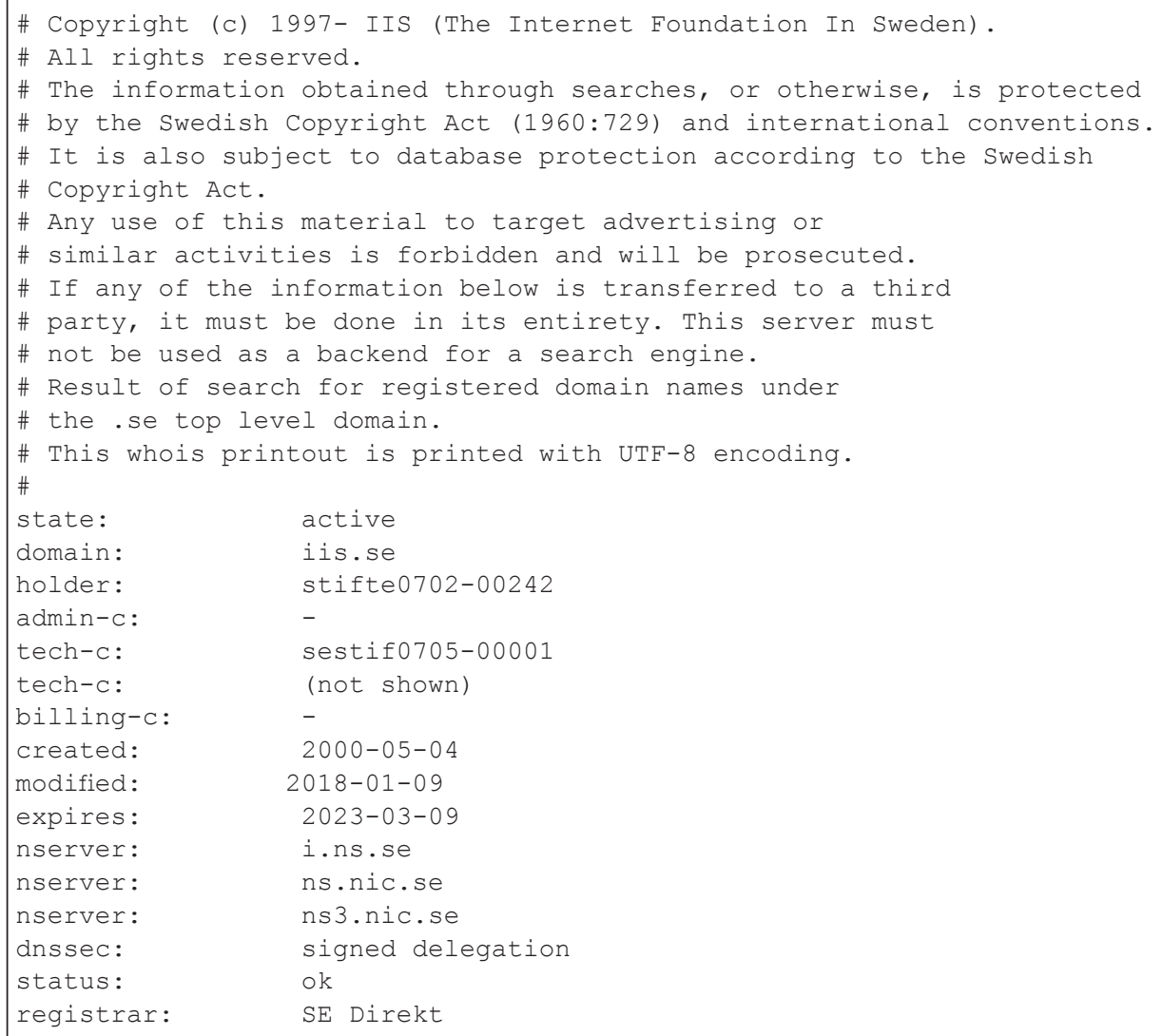

Source: The Internet Foundation in Sweden (IIS, 2018) 


\section{Ownership and policies}

\subsection{Regulations}

In the field of TLDs there is no specific harmonized regulation system which TLD owners are obligated to use although certain common principles and cooperation exist. ICANN creates certain frames at the registry agreement, however those in general do not limit owner rights: usually owners can create a policy how to grant SLD names as they want (ICANN, 2000). We need to distinguish registry operator from the TLD owner because they are not automatically the same entity: the owner could be for example a company which has brand TLD or a government which has its own ccTLD and then they have separate service providers which act as registry on behalf of them. There are large registry operators, e.g. Donuts Inc., which operates as registry for more than 200 TLDs (e.g., .legal) and also small operators such as Ålands Telekommunikation Ab (Ålands landskapsregering, .ax) and the Department of Telecommunications (Holy See, .va), which is a government-based registry operator (IANA, 2017a; IANA, 2016; ICANNWiki, n.d., a). Often ccTLDs are controlled by national legislation, which develops a policy to grant domain names and, for example, requires the holder to be a resident of the state, or determines whether the domain is publicly available or, e.g., only for trademark holders (Bettinger, 2005, pp. 37-38; UNINETT, 2017). With gTLDs, there is no standardized way and therefore the operator of the registry defines domain name policy and cooperates, for example, with sponsored and brand TLDs, which means that the third parties may have no right to register domain names (Nokia, n.d.). The system is somewhat similar to the system of phone number prefixes, although the International Telecommunication Union (ITU) controls how the prefixes are granted to states (and the states have the right to create their own numbering plan) (ITU, n.d.).

\subsection{Policy}

Since TLD owners can define the policy of how to grant domain names, there exist many types of them. With TLDs, where SLD registrations are generally available, the most common way is to reserve a special right for trademark owners to get a domain name matching the trademark (there may be also a sunrise period, which means that before general availability trademark owners have early access to register domain names matching their international trademark) (WIPO, n.d., a; Avdenja, 2015; ICANN, 2018b). This means that in cases of new registration, the registry operator checks whether there are no trademarks the 
right of which could be violated, and if a TLD is only available for trademark holders, then checks whether the application details match or the trademark holder has the right to make a complaint if someone else has registered the domain name in bad faith while the domain name is generally available (Litman, 2000). One widely recognized principle is "first come, first served", which gives the right to keep registered domain names even if there is a trademark although it requires that the domain name was registered before the registration of the trademark or an existing right overwrites it (e.g., national registered tradename) and also all other legal requirements at the time of registration should be fulfilled. (Jokinen, 2016, pp. 66-69)

\section{WIPO ccTLD complaints 2018}

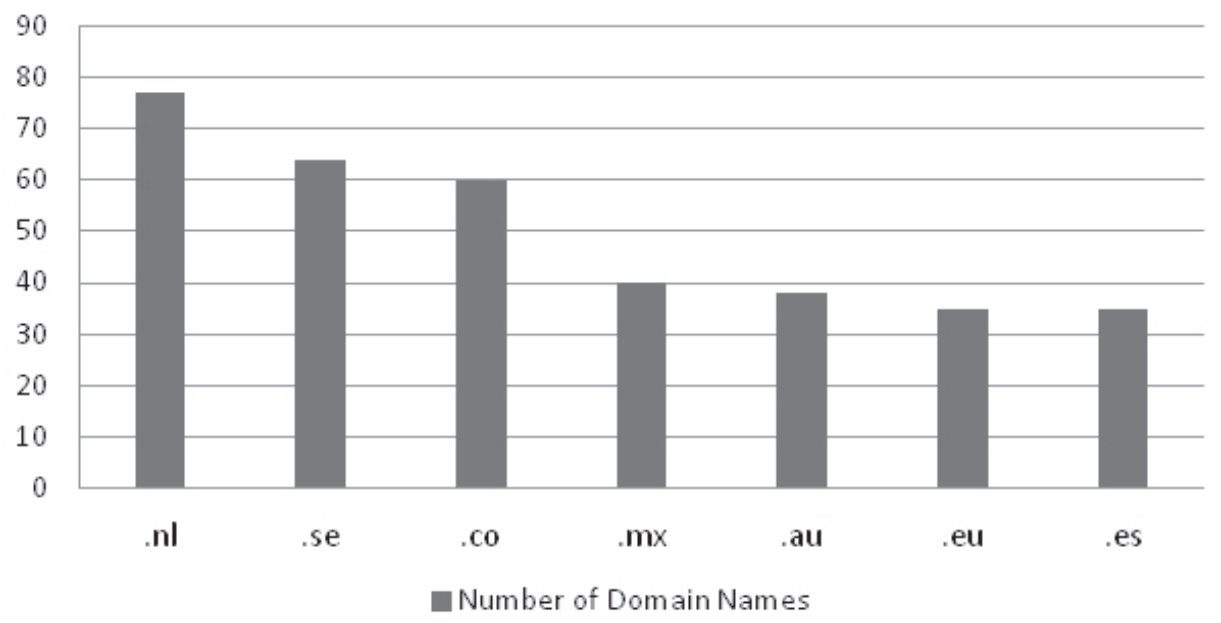

Figure 1. Seven most popular WIPO ccTLD complaints in 2018

Source: (WIPO, 2018)

Some TLDs use the ICANN's Uniform Domain-Name Dispute-Resolution Policy (UDRP) to deal with trademark complaints (ICANN, n.d.). Among European ccTLDs, TLDs are in most cases controlled by a national agency which is required to follow national law: some ccTLDs, however, have adopted UDPR as part of their procedures. A common way to deal with trademark complaints is alternative dispute resolution (ADR), which is usually governed by UDRP. There are several ADR providers and, for example, the World Intellectual Property Organization (WIPO) and the Czech Arbitration Court (CAC) provide these dispute services in which CAC is the official eu dispute provider (CAC, 
n.d., a). Also national courts can be used to solve disputes or, after a case is decided using ADR parties, they may have the right to take the case to national court (some ccTLDs allow that). For example, .fi ccTLD uses a system where the national agency, Finnish Communication Regulatory Authority (FICORA), decides how the existing legislation or previously held prejudices should be applied (a kind of replacement for ADR) and after the decision is held, both parties have the right to complain and ask that court ruled in favor of the plaintiff (FICORA, 2016a). When the UDRP system is used, either law maker gives jurisdiction over to the arbitration panel or the gTLD owner decides to do so, as in certain circumstances it could create problems.

Few ccTLDs (e.g., .se and .nl) receive a high number of complaints compared to even popular gTLDs (e.g., .org and .net) when proportionated to the number of registrations (WIPO, n.d., c). The reason is that normally the process to make complaints costs fees which vary in sum: some ccTLDs have lower rates for dispute resolution meaning that the threshold to initiate the process is usually lower than with other TLDs (e.g., .se min. 4,000 SEK vs. .net 1,500 USD) (WIPO, n.d., d). Policies partially reflect the society's attitudes: some states see that legal remedies should be available and accessible for everyone regardless of their financial conditions (i.e. not only for gigantic corporations).

\section{European Union TLD and the Brexit}

\subsection{Brexit in general}

In 2016, the Brexit referendum was held in the United Kingdom, which changes the path of the European Union and is going to end the 40-year relationship between the EU and the UK (Al-Nuemat \& Nawafleh, 2017, p. 116). UK is among the top five EU economies and therefore it carries substantial economic weight (Dutt et al., 2018; Ferraro et al., 2017). Brexit is going to have a major impact on both the United Kingdom's and the European Union's economy if it restricts freedom of movement. The legal backround for the Brexit was set at the time of drafting the Lisbon Treaty where Article 50 of the Treaty on the European Union (TEU) regulates the framework for the withdrawal of a Member State from the Union (Kertesz, 2016; Treaty of Lisbon, 2007; Al-Nuemat \& Nawafleh, 2017, p. 120; Craig, 2017). Former Prime Minister of the UK David Cameron promised that if their Conservative Party won the election and he became prime minister they are going to organize elections regardless of whether the UK will stay in the EU or leave (Osborn \& Griffiths, 2013). These elections turned out to be far more than just usual walkover: especially when withdrawal notice was given about 
the Brexit to the European Union and 29 March 2019 was set up to the exact date (Ruth, 2018). The process has not gone far and negotiations are still going on (Kuenssberg, 2018). No promises to reach an economic deal between the EU and the UK (which is, e.g., a member of the EEA) have been made and even less related to the Union's TLDs - the future seems unclear.

\subsection{TLD in general and its history}

The TLD of the European Union, .eu, is operated by EURid (IANA, 2017b). The evolution of the the domain began in the early 2000s when the European Union applied for its own domain name due to its getting its own ISO 3166-1 code EU (ICANN, n.d., b). This application to obtain its own TLD is similar to what the European Union had with its telephone number (although the domain process continues, while the telephone number plans were discontinued). The Union was interested in getting its own telephone code +388 and around the mid-1990s there were also plans to receive +3 single numbering plan in Europe (European Commission, 1996). With the .eu TLD, the process has continued well and in 2007, a year after its launch, almost 3 million domain names have been registered (European Commission, 2009). Nowadays the .eu TLD has over 3.8 million registered SLDs and a position at ccTLD ranking in top ten most popular TLDs (Verisign, 2018).

\subsection{The effects of the Brexit to domain holders}

When the United Kingdom leaves the European Union (on the background see Ramiro Troitiño et al., 2018), it is no longer part of the EEA/EFTA (hard Brexit, if the agreement not reached) and therefore, individuals and entities residing in the UK cannot be .eu domain registrants. The European Commission has stated that they are going to revoke all UK registrant owned .eu domain names after they leave the Union and that might cause quite a few challenges for UK domain holders (McCarthy, 2018). It can also be possible that the Commission finds a way to solve the problem if they make some kind of a deal with the UK (e.g., soft Brexit). Since the .eu TLD is controlled by the Union regulations there might still be issues which require modifications to existing regulations. There are certain common ways to exclude a domain from a certain group (restrict the right to register, etc.) and those could be used in the case. Revoking of all domain names (which in this context means restricting denying prolongation of registration) could be unprecedented in the history of domain names (and probably has not been done in the past in the scale of eu domain name if revocation due to the Brexit is going to take place). 
Prolonging a domain name means that the domain holder (SLD owner) has the right to renew the domain name before its expiration date and by doing that retains the right to hold the domain name (Digital Internet, 2016). The same method has been used with trademarks. The standard registration period of a trademark is usually 10 years and after that the trademark owner has the right to renew it (WIPO, n.d., b). With domain names, the basic registration time is one year although domains can be usually renewed for up to 10 years. (ICANN, 2017) If the Commission denies UK-based domain owners the possibility to renew domain names, it would violate the basic idea that the holder could retain the right after its expiration if the right is renewed as needed. This is a crucial part of trademark law and these registered rights could be restricted in general only through court order (see, e.g., the trademark case of Skyr in Kavli Holding $A S$ v. Skånemejerier $A B$ [2015]). If the possibility of renewing a domain name is taken away then all domains are going to expire: in practice, this would mean that the Commission is going to revoke these domain names.

In general, there is a principle that if the right has already be granted it should beens not taken away without a special reason. This idea is followed by almost all TLDs (a domain name cannot be taken away without carefully defined reason under, e.g., national legislation or court order) and, generally, the right to own a domain is based on the time when the domain was registered (retroactivity is usually not allowed although bad faith could impair that principle). In that sense, the .eu domain owners in the UK who have registered the .eu domain name before the Brexit should retain the ownership in future, even though new registrations are not allowed - this custom is called grandfathering (McCarthy, 2018). The Commission might have actual legal power to revoke all domains although it might cause a problematic legal situation because a right already granted usually cannot be taken away.

Legal certainty is important in the field of law and it should not be violated. Domain names are usually seen as property granted pursuant to a contract although they are subject to certain obligations which are subject to trademark law (Burshtein, 2005). Article 17(1) of the Charter of Fundamental Rights of the European Union states that "Everyone has the right to own $[\ldots]$ his or her lawfully acquired possessions. No one may be deprived of his or her possessions, except in the public interest and in the cases and under the conditions provided for by law" and Article 17(2) specifically mentions that "Intellectual property shall be protected" (Charter of Fundamental Rights of the European Union, 2000). Therefore there should be a legal basis to restrict the right of ownership and these rules should apply to all actions taken by the European Commission: as the Charter of Fundamental Rights of the European Union states, all these 
basic rights should be protected and a person could be deprived of the right to enjoy and hold property only in case of public interest which specifically requires that there is legislation which precisely defines how these rights are violated (law should not be unambiguous in this area).

\subsection{Examples from the Union and the Member States}

There have been similar cases in the Member States and the Union in which existing national legislation plays a major role in revoking already given rights.

In a case of conflict between the Union's driving license directive and the national law of a Member State, driver's licenses were granted with a longer period of validity, which is permitted by the Directive. Article 3 of the EU's driving license directive states that "Member States shall ensure that, by 19 January 2033, all driving licenses issued or in circulation fulfil all the requirements of this Directive" (Directive 2006/126/EC). Some Member States had already issued driving licenses with a longer validity period (e.g., Germany has issued some driving licenses without an expiration date) (The Local, 2010). There was a legal conflict because the authority already had issued driving licenses with a longer expiration date. Since the Directive clearly states that as of 19 January 2033 there should be only driving licenses which follow the Directive, those existing driving licenses should be revoked. Because of that, for example, German national legislation, Section 24a of the Fahrerlaubnis-Verordnung states that "driver's licenses issued before 19 January 2013 must be exchanged by 19 January 2033" (FahrerlaubnisVerordnung, 2010). Under national legislation, it is possible to restrict the existing given rights although it requires special legislation which clearly states that. In that sense, it might be possible that the Commission will be violating domain holders' rights if they revoke the domain names without justifying it with legislation.

There is also an upcoming new proposal for identity documents in the EU from the Commission which also defines the lawmaker's power to revoke given existing rights. The Commission has proposed that all EU Member States are required to add facial images and fingerprints to their national identity documents within a 5-year-period (non-machine readable cards in only 2 years) (European Commission, 2018; Blenkinsop \& Koester, 2018). This basically means that some Member States need to revoke ID cards even though they have already been issued and have legal validity according to national legislation (e.g., Austria has already issued ID cards with a 10-year validity period) (European Union, 2010). This mass ID card revoke is going to require some sort of national legislation from the part of the Member State, possibly concluded through a directive similarly to driving licenses. 
There was a case in Estonia where national identity document certificates were revoked on a mass scale due to vulnerability (Information System Authority, 2017). These actions require a legal basis which should be properly defined and give the authorities the power to revoke or suspend these certificates. Article 9(5) of the Estonian Identity Documents Act states that "The issuer of the document may suspend the validity of the certificate entered into the identity document and restore the validity of the suspended certificate under the conditions provided [...] in [...] Electronic Identification and Trust Services for Electronic Transactions Act" (Identity Documents Act, 2000). Article 17(1) of the Electronic Identification and Trust Services for Electronic Transactions Act regulates suspension of certificates and gives the authorities the power to suspend certificates and Article 19(4) specifies the situation when there is a possibility that "using the private key corresponding to a public key contained in the certificate without the consent of the certificate holder". The area is regulated not only by national legislation but also by the European Union with its regulation which provides a context for defining the understanding of certificates and the revocation process (Police and Border Guard Board, 2018, pp. 13-14). The Regulation for electronic identification and trust services for electronic transactions in the internal market (eIDAS) regulates the area from the aspect of the European Union and lays foundation for a mutual recognition of certificates among Member States and secure crossborder electronic identification and trust services (Kerikmäe \& Särav, 2015 , pp. 74, 82). Article 10 of eIDAS provides that in case of security breach, certificates should be suspended or revoked and the Member States and the Commission informed after the event (Regulation (EU) 910/2014). Due to the well defined and constructed legal background, Estonia was able to first suspend the certificates and then revoke all the certificates that were not renewed: had there not been such legal backround, it would have been really difficult to take rapid action.

There have been many revocations of eu domain names through court order. Probably the best known is the case of Ms. Zheng: almost 9,000 EU domain names owned by Ms. Zheng were revoked when the Brussels Court of Appeals found that all the domains were registered in bad faith and, as a result, those domain names should be revoked from the registry (EURid, 2011). Article 21(1) of the Commission Regulation "laying down public policy rules concerning the implementation and functions of the .eu Top Level Domain and the principles governing registration" states that "A registered domain name shall be subject to revocation $[\ldots]$ that name is identical or confusingly similar $[\ldots]$ and $[\ldots]$ has been registered or is being used in bad faith". Through the regulation, the 
court has the power to make decisions and give permission for a registry to revoke all those domain names. The case is not exceptional although the scale was unique. Revokes in smaller amounts also exist and EURid has done them regularly (CAC, n.d., b).

Also EURid has carried out revoke processes based on existing regulations and in 2018 they announced that over 36,000 domain names are going to be revoked due to non-eligible registration data. (EURid, n.d., b). Based on the factors mentioned, the registry has already done major revokes and that operation is not exceptional. There is no court or arbitration panel pointing out whether a domain holder violates regulations and therefore legal background might be problematic. In the case of the Brexit the justification for revoking the .eu domain name is not based on active violation from the registrant's side.

\subsection{Methods}

There are certain ways how the Commission could deal with the situation and three possible scenarios are presented below:

\section{a) Revoking domain names from the registry}

It is possible that the Commission indeed will revoke all domain names from the registry at the time when the Brexit process takes effect in 2019 (as the press release states). This means that the UK domain holders will lose the right to keep their domain names. Technically, this means that the domain holder has no possibility to renew their domains after the Brexit although they can use them normally up to the expiration date. After that, the domains are generally available for registration (domain expiration date plus usually the quarantine period), which may cause a large wave of eu domain name drop catching and through that also cause problems to the previous domain owners in the form of cybersquatting (Golinveaux, 1999). This method will bring about a race to establish subsidiary companies inside the European Union among UK-based companies and may also create an illegal market for domain proxy services. For example, the Republic of Estonia has informed that a UK corporation has the right to retain their .eu domain names if they establish a subsidiary company in Estonia (Rang, 2018).

\section{b) Maintaining the existing situation (making an exception)}

The Commission may also create an exception so that the existing domain holders could keep their domain names (and renew them as usual); however, new registrations are not allowed under the .eu TLD (grandfathering). This method does not violate the basic principles of domain names (it is a 
commonly recognized principle that the owner has the right to renew the domain). This method might require changes to Regulation (EC) 733/2002, Article 4(2)(b) of which defines the general eligibility criteria for .eu domain registrants:

- Undertaking having its registered office, central administration or principal place of business within the Community, or

- Organization established within the Community without prejudice to the application of national law, or

- Natural person resident within the Community.

\section{c) Deal between the EU and the UK}

There is always a possibility that the United Kingdom finds a solution with the European Union so that individuals and companies in the UK can have the right to be registrants of eu domain names in the future. We are still waiting for the decision of what will be the method of the Brexit (negotiations are still ongoing). There are two widely known options for the Brexit: a hard and a soft one (Sims, 2016). A second option might be that the UK still stays in the single market area (on the various options, impacts and private international law implications see Hoffmann, 2018), meaning that it continues as an EEA/EFTA member state (for example, the same status which Norway has) and therefore holders also then retain their right to be registrants. Using this method does not require changing any regulations due to the fact that the residents of EEA/EFTA member states have the right to register .eu domain names (EURid, n.d., c).

\section{Trademarks and trademark holders}

Many UK-based companies are holders of European Union trademarks and those trademark owners had the special right to get .eu domain name during the sunrise period before the normal registration begins. If those currently registered domain names expire due to the Brexit, it is possible that other parties will try to register these domain names and then cause problems to trademark holders (e.g., data phishing, cybersquatting and trademark infringement). Under Commission Regulation (874/2004) there is a possibility to remove the registered domain name from the registry. Article 21 states that:

A registered domain name shall be subject to revocation $[\ldots]$ where that name is identical or confusingly similar to a name in respect of 
which a right is recognised $[\ldots]$ and where it $[\ldots]$ has been registered by its holder without rights or legitimate interest in the name [...] or [...] has been registered or is being used in bad faith. (Commission Regulation (EC) 874/2004)

The only option for EU trademark holders situated in the UK after the possible hard Brexit from the technical perspective is to let the domain name expire and then if someone uses a domain name to violate their rights initiate the usual proceedings to revoke the domain name from the registry. This could, in theory, create an endless treadmill, causing an unnecessary and harmful bureaucratic legal limbo.

Usually, ADR is significantly more expensive compared to the option that a trademark owner holds ownership of the domain name (some tens of euros per year) - the ADR process at WIPO costs at least 1,500 USD and at CAC 1,300 EUR (CAC, n.d., c). With the .eu domain, a trademark holder has the right to complain; however, for UK companies it might cause problems because they cannot register or ask that domain to be transferred to them and the only option is to take it to the ADR procedure (after the process the domain will be again publicly available and another party could then register it and the same process might start all over). Some ccTLDs have a special opportunity to make complaints against domain holders if there is a registered trademark which is identical to the domain name (bad faith is not necessarily required): unfortunately, this option is not available for the .eu TLDs and the case always needs to be taken first to dispute resolution.

\section{Conclusion}

Domain names are here to stay and they are an integrated part of online world today. It is crucial that they are working properly and the regulations governing the domain names are clear and visible for the owners. Obviously, also intellectual property rights should be taken into account when creating policies for domain names and also systems should be harmonized and secured to ensure their maximum stability. It is crucial that the central operations of root registry are handled at least by a nonprofit organization which does not have direct ties to any government. It would still be justified that control should be transferred to a recognized international organization, such as the United Nations, which could handle policies to issue new TLDs owing to the fact that it can create more stability and reliability. 
The Brexit process creates problems in general for the EU and a good example of that is the situation with domains: even the founding negotiations have not gone far and therefore it is not realistic to expect a breakthrough outcome quickly. It is clear that if a Member State leaves the Union, citizens and legal entities should no longer have the right to possess any domain names since the regulations do not allow that. On the other hand there are also basic fundamental rights which should be respected and unnecessary actions should not be taken. All actions should be justified and adjusted in proportion to the situation and there should be a broader discussion among governments. The Commission's actions are realistic in a way that if Brexit is going to take place as planned there will be a conflict from the legal perspective if nothing is done. On the other hand, the situation is not surprising because the UK is well aware of the consequences when they began the withdrawal process from the Union after the referendum.

Nevertheless, rights should be protected because othervise the holders cannot rely on the fact that they have the possibility to renew domain names in the future - as a result, the trust to the .eu domain name might weaken. Legal certainty is important in the sphere of domain names and all parties should try to always keep that as a goal, otherwise we could miss our foundation - the rule of law.

Touko Johannes Sinisalo studies law at Tallinn Law School of Tallinn University of Technology and is specialised in European Union and international law. For the past five years, he has worked as a consultant in the field of information technology and media. Sinisalo focuses his research activities on law and technology, specifically privacy and data protection issues, communications and information law, and intellectual property rights. 


\section{References}

Al-Nuemat, A. \& Nawafleh, A. (2016), 'Brexit, arbitration and private international law,' Journal of Politics and Law, vol. 10, no. 5, pp. 116-123. https://doi.org/10.5539/jpl.v10n5p116

Avdenja, N. (2015), Legal Protection for Trademarks from Registered Generic TopLevel Domain Names, BA thesis, Tallinn University of Technology, Tallinn.

Bettinger, T. (2015), Domain Name Law and Practice: An International Handbook, NewYork: Oxford University Press.

Blenkinsop, P. \& Koester, S. (2018), 'EU Commission proposes making fingerprints mandatory in ID cards,' Reuters, 17 April. Retrieved from https://www.reuters. com/article/us-eu-security/eu-commission-proposes-making-fingerprintsmandatory-in-id-cards-idUSKBN1HO23A [accessed 16 Oct 2018]

Burshtein, S. (2005), 'Is a domain name property?' Journal of Intellectual Property Law \& Practice, vol. 1, no. 1, pp. 59-63. https://doi.org/doi:10.1093/jiplp/jpi019

CAC (n.d., a), 'About the Czech Arbitration Court,' Czech Arbitration Court. Retrieved from https://eu.adr.eu/about_us/court/index.php [accessed 18 Oct 2018]

CAC (n.d., b), 'Decisions,' Czech Arbitration Court. Retrieved from https://eu.adr.eu/ adr/decisions/index.php [accessed 18 Oct 2018]

CAC (n.d., c), 'Fees,' Czech Arbitration Court. Retrieved from http://eu.adr.eu/adr/fees/ index.php [accessed 18 Oct 2018]

Charter of Fundamental Rights of the European Union (2000), OJ C 326, 18.12.2000. Retrieved from https://eur-lex.europa.eu/legal-content/EN/ TXT/?uri=CELEX:12012P/TXT [accessed 18 Oct 2018]

Commission Regulation (EC) No 874/2004 of 28 April 2004 laying down public policy rules concerning the implementation and functions of the .eu Top Level Domain

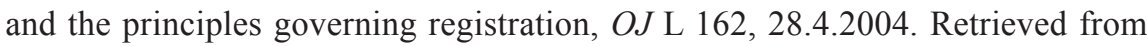
http://data.europa.eu/eli/reg/2004/874/oj [accessed 17 Oct 2018]

Craig, P. (2018), 'The Process: Brexit and the Anatomy of Article 50,' in F. Fabbrini (eds.) The Law and Politics of Brexit, Oxford: Oxford University Press, pp. 49-70. https://doi.org/10.1093/oso/9780198811763.003.0003

DARPA (n.d.), Paving the Way to the Modern Internet, Defense Advanced Research Projects Agency. Retrieved from https:/www.darpa.mil/about-us/timeline/ modern-internet [accessed 20 Oct 2018]

DENIC (2016), Public-whois: Documentation. Retrieved from https:/www.denic.de/ fileadmin/public/documentation/DENIC-12p_EN.pdf [accessed 20 Oct 2018]

Digital Internet (2018), 'Why you must not forget to renew your domain name.' Retrieved from https://digital-internet.com/renew-domain-name/ [accessed 20 Oct 2018] 
Directive 2006/126/EC of the European Parliament and of the Council of 20 December 2006 on driving licences, $O J$ L 403, 30.12.2006. Retrieved from http://data.europa. eu/eli/dir/2006/126/oj [accessed 20 Oct 2018]

Dobrin, S. \& Chochia, A. (2016), 'The concepts of trademark exhaustion and parallel imports: a comparative analysis between the EU and the USA,' Baltic Journal of European Studies, vol. 6, no. 2, pp. 28-57. https://doi.org/10.1515/bjes-2016-0011

Domain Name Act (2006), Finland Ministry of Justice, 3.1.2006. Retrieved from https:// www.finlex.fi/en/laki/kaannokset/2003/en20030228.pdf [accessed 20 Oct 2018]

Dutt, P.; Ferraro, S.; Chochia, A. \& Muljar, R. (2018), 'Using patent development, education policy and research and development expenditure policy to understand differences between countries - the case of Estonia and Finland,' Baltic Journal of European Studies, vol. 8, no. 1, pp. 123-153.

https://doi.org/10.1515/bjes-2018-0008

EURid (2011), '9,000 .eu. domain names revoked following court decision,' EURid.eu, 20 October. Retrieved from https://eurid.eu/nl/nieuws/9-000-eu-domain-namesrevoked-following-court-decision/ [accessed 20 Oct 2018]

EURid (n.d., a), 'Eurid.eu public WHOIS information,' Retrieved directly from registry [accessed 20 Oct 2018]

EURid (n.d., b), 'Over 36000 suspended domain names withdrawn,' EURid.eu. Retrieved from https://eurid.eu/nl/nieuws/suspended-dns-withdrawn/ [accessed 17 Oct 2018]

EURid (n.d., c), 'Register a domain name,' EURid.eu. Retrieved from https://eurid.eu/ en/register-a-eu-domain/ [accessed 20 Oct 2018]

EURid (n.d., d), 'WHOIS Policy', EURid.eu. Retrieved from https://eurid.eu/d/205797/ whois_policy_en.pdf [accessed 20 Oct 2018]

European Commission (1996), Green Paper on a Numbering Policy for Telecommunications Services in Europe, Commission of the European Communities, Ministry for EU Affairs, 20.10.1996. Retrieved from https:// www.ab.gov.tr/files/ardb/evt/1_avrupa_birligi/1_6_raporlar/1_2_green_papers/ com1996_green_paper_on_a_numbering_policy_telecommunications_services in_europe.pdf [accessed 20 Oct 2018]

European Commission (2009), '.eu domain passes the 3 million mark,' Commission of the European Communities, IP/09/48, 14.1.2009. Retrieved from http://europa.eu/ rapid/press-release_IP-09-48_en.htm [accessed 20 Oct 2018]

European Commission (2018), 'Security Union: Commission presents new measures to deny terrorists and criminals the means and space to act' European Commission - Press release. Retrieved from http://europa.eu/rapid/press-release_IP-18-3301_ en.htm [accessed 31 Aug 2018]

European Union (2010), 'Document: AUT-BO-02003,' General Secretariat of the Council of the European Union. Retrieved from https://www.consilium.europa. eu/prado/en/AUT-BO-02003/index.html [accessed 20 Oct 2018] 
Fahrerlaubnis-Verordnung (2010), German Federal Ministry of Justice (juris GmbH), 13.12.2010. Retrieved from https://www.gesetze-im-internet.de/fev_2010/ BJNR198000010.html [accessed 20 Oct 2018]

Ferraro, S.; Dutt, K. P. \& Kerikmäe, T. (2017), 'Using patent development, education policy and research and development expenditure policy to increase technological competitiveness of small European Union Member States, 'Croatian International Relations Review, vol. 23, no. 78, pp. 97-126.

https://doi.org/10.1515/cirr-2017-0009

FICORA (2016a), 'Domain name dispute resolution,' Finnish Communications Regulatory Authority. Retrieved from https://www.viestintavirasto.fi/en/ fidomain/domainnamedisputeresolution.html [accessed 20 Oct 2018]

FICORA (2016b), 'Protected name or trademark,' Finnish Communications Regulatory Authority. Retrieved from https:/www.viestintavirasto.fi/en/ fidomain/domainnamedisputeresolution/protectednameortrademark.html [accessed 20 Oct 2018]

Finley, K. (2016), 'The internet finally belongs to everyone,' Wired, 10 March. Retrieved from https://www.wired.com/2016/10/internet-finally-belongs-everyone/ [accessed 20 Oct 2018]

Golinveaux, J. (1999), 'What's in a domain name: is cybersquatting trademark dilution?' University of San Francisco Law Review, vol. 33, no. 4, pp. 641-672. Retrieved from https://heinonline.org/HOL/P?h=hein.journals/usflr33\&i=651 [accessed 20 Oct 2018]

Hoffmann, T. (2018), 'The Brexit and private international law: an outlook from the consumer insolvency perspective,' in D. Ramiro Troitino; T. Kerikmäe \& A. Chochia (eds.) Brexit: History, Reasoning and Perspectives, Cham: Springer International Publishing, AG, pp. 237-248. https://doi.org/10.1007/978-3-319-73414-9_14

Hover (2017), 'What is a domain hack?' Hover Blog, 3 March. Retrieved from https:// www.hover.com/blog/what-is-a-domain-hack/ [accessed 20 Oct 2018]

IANA (2016), 'Delegation Record for .va,' Internet Assigned Numbers Authority. Retrieved from https://www.iana.org/domains/root/db/va.html [accessed 20 Oct 2018]

IANA (2017a), 'Delegation Record for .ax,' Internet Assigned Numbers Authority. Retrieved from https://www.iana.org/domains/root/db/ax.html [accessed 20 Oct 2018]

IANA (2017b), 'Delegation Record for .eu,' Internet Assigned Numbers Authority. Retrieved from https://www.iana.org/domains/root/db/eu.html [accessed 20 Oct 2018]

IANA (n.d.), 'Technical requirements for authoritative name servers,' Internet Assigned Numbers Authority. Retrieved from https://www.iana.org/help/nameserverrequirements [accessed 20 Oct 2018] 
ICANN (n.d.), 'Uniform Domain-Name Dispute-Resolution Policy', The Internet Corporation for Assigned Names and Numbers. Retrieved from: https://www. icann.org/resources/pages/help/dndr/udrp-en [accessed 20 Oct 2018]

ICANN (2000), 'Description of TLD policies,' The Internet Corporation for Assigned Names and Numbers. Retrieved from https://archive.icann.org/en/tlds/fin1/ TLD\%20web/TLD\%20policy.htm [accessed 20 Oct 2018]

ICANN (2017), '.NET Registry Agreement,' The Internet Corporation for Assigned Names and Numbers. Retrieved from https:/www.icann.org/sites/default/files/ tlds/net/net-proposed-renewal-19apr17-en.pdf [accessed 20 Oct 2018]

ICANN (2018a), 'Data Protection/Privacy Issues,' The Internet Corporation for Assigned Names and Numbers. Retrieved from https://www.icann.org/dataprotectionprivacy [accessed 20 Oct 2018]

ICANN (2018b), 'Trademark Clearinghouse FAQ,' The Internet Corporation for Assigned Names and Numbers. Retrieved from https://newgtlds.icann.org/en/ about/trademark-clearinghouse/faqs [accessed 20 Oct 2018]

ICANN v. EPAG Domainservices GmbH [2018], Appellate Court of Cologne, 29 May, no. $10 \mathrm{O} 171 / 18$.

ICANNWiki (n.d., a), 'Donuts,' ICANNWiki. Retrieved from https://icannwiki.org/ Donuts [accessed 20 Oct 2018]

ICANNWiki (n.d., b), 'Domain name .eu,' ICANNWiki. Retrieved from https:// icannwiki.org/.eu [accessed 20 Oct 2018]

ICANNWiki (n.d., c), 'Domain name .gov,' ICANNWiki. Retrieved from https:// icannwiki.org/.gov [accessed 20 Oct 2018]

ICANNWiki (n.d., d), 'Domain name .stockholm,' ICANNWiki. Retrieved from https:// icannwiki.org/.stockholm [accessed 20 Oct 2018]

Identity Documents Act (2000), Government of Estonia, 1.1.2000. Retrieved from https:// www.riigiteataja.ee/en/eli/528032017002/consolide [accessed 20 Oct 2018]

IIS (2000), 'IIS.se public WHOIS information,' The Internet Foundation in Sweden. Retrieved from https://www.iis.se/english/domains/free/ [accessed 20 Oct 2018]

Information Society Code (2014), Finland Ministry of Transport and Communications, 11.7.2000. Retrieved from https://www.finlex.fi/en/laki/kaannokset/2014/ en20140917.pdf [accessed 17 Oct 2018]

Information System Authority (2017), 'Background information on the ID card security vulnerability and update process.' Retrieved from https://www.id.ee/index. php?id=38245 [accessed 20 Oct 2018]

ITU (n.d.), 'National numbering plans,' International Telecommunication Union. Retrieved from http://www.itu.int/oth/T0202.aspx?parent=T0202 [accessed 20 Oct 2018]

Jafferali, S. (2016), 'Build your own anycast network in nine steps' (Réseaux IP Européens), RIPE, 19 December. Retrieved from https://labs.ripe.net/Members/samir_jafferali/ build-your-own-anycast-network-in-nine-steps [accessed 20 Oct 2018] 
Jokinen, T. (2015), Yksinoikeus toiminimeen, MA thesis, University of Lapland, Rovaniemi.

Kavli Holding $A S$ v. Skånemejerier $A B$ [2015], Patent- och registreringsverket, Swedish Patent and Market Court judgment no. 15-027, 17.12.2015. Retrieved from http:// avgoranden.domstol.se/Files/PBR/PBRdom/PBR_15_027_dom.pdf [accessed 20 Oct 2018]

Kerikmäe T. \& Särav S. (2016), 'Legal impediments in the EU to new technologies in the example of e-residency,' Baltic Journal of Law \& Politics, vol. 8, no. 2, pp. 71-90. https://doi.org/10.1515/bjlp-2015-0019

Kertesz, A. (2016), 'Brexit's legal framework,' ELTE Law Journal, vol. 1, no. 1, pp. 93-102. Retrieved from https://heinonline.org/HOL/P?h=hein.journals/ eltelj2016\&i=93 [accessed 20 Oct 2018]

Kuenssberg, L. (2018), 'Are delaying tactics the answer for May?' BBC, 17 October. Retrieved from https://www.bbc.com/news/uk-politics-45882356 [accessed 20 Oct 2018]

Litman, J. (2000), 'The DNS wars: trademarks and the internet domain name system essay,' Journal of Small and Emerging Business Law, vol. 4, pp. 149-166. Retrieved from https://heinonline.org/HOL/P?h=hein.journals/jsebl4\&i=161 [accessed 20 Oct 2018]

McCarthy, K. (2018), 'Europe dumps 300,000 UK-owned .EU domains into the Brexit bin,' The Register (Situation Publishing), 29 March. Retrieved from https:// www.theregister.co.uk/2018/03/29/eu_dumps_300000_ukowned_domains_into_ brexit_bin/ [accessed 20 Oct 2018]

Mockapetris, P. (1987), 'IETF,' Domain names - Concepts and facilities. Retrieved from https://tools.ietf.org/pdf/rfc1034.pdf [accessed 20 Oct 2018]

Myles, P. (2014), 'ccTLDs \& national legislation: regional organisation collaborative survey,' ICABB Archives. Retrieved from https://archive.icann.org/meetings/ losangeles2014/en/schedule/wed-ccnso-members/presentation-cctlds-nationallegislation-15oct14-en.pdf [accessed 20 Oct 2018]

Nokia (n.d.), 'NOKIA domain name terms \& conditions,' Retrieved from https://portal. icann.org/servlet/servlet.FileDownload?file=00P6100000FPCOVEA5 [accessed 20 Oct 2018]

Nyman-Metcalf, K.; Dutt, P. K. \& Chochia, A. (2014), 'The freedom to conduct business and the right to property: the EU technology transfer block exemption regulation and the relationship between intellectual property and competition law,' in T. Kerikmäe (ed.) Protection of Human Rights in the EU: Controversies and Challenges of the Charter of Fundamental Rights, Cham: Springer Verlag, pp. $37-70$.

Ramiro Troitino, D.; Kerikmäe, T. \& Chochia, A., eds. (2018), Brexit: History, Reasoning and Perspectives, Cham: Springer International Publishing. https://doi.org/10.1007/978-3-319-73414-9 
Osborn, A., \& Griffiths, P. (2013), 'UK EU referendum: David Cameron promises in-out vote in 2015,' Huffington Post. Retrieved from https://www.huffingtonpost. com/2013/01/23/uk-eu-referendum-vote-david-cameron-in-out-vote2015_n_2531591.html [accessed 18 Oct 2018]

Police and Border Guard Board (2018), Estonian eID scheme: ID card. Retrieved from https://ec.europa.eu/cefdigital/wiki/download/attachments/62885749/EE\%20 eID\%20LoA\%20mapping\%20-\%20ID\%20card.pdf [accessed 17 Oct 2018]

Rang, A. (2018), 'How to register a .EU domain from anywhere (or keep it after Brexit)', E-Residency Blog (Republic of Estonia), 26 January. Retrieved from https:// medium.com/e-residency-blog/how-to-register-a-eu-domain-from-anywhere-orkeep-it-after-brexit-b630d893f13 [accessed 20 Oct 2018]

Regulation (EU) No 910/2014 of the European Parliament and of the Council of 23 July 2014 on electronic identification and trust services for electronic transactions in the internal market and repealing Directive 1999/93/EC, OJ L 257, 28.8.2014. Retrieved from http://data.europa.eu/eli/reg/2014/910/oj [accessed 17 Oct 2018]

Ruth, L. (2018), 'Trading with the EU post Brexit: the WTO option is perfectly feasible.' Retrieved from http:/www.arbuthnotgroup.com/upload/marketmatter/ documents/6_august_2018.pdf [accessed 17 Oct 2018]

Sims, A. (2016), 'What is the difference between hard and soft Brexit? Everything you need to know,' The Independent, 10 March. Retrieved from https://www. independent.co.uk/news/uk/politics/brexit-hard-soft-what-is-the-difference-ukeu-single-market-freedom-movement-theresa-may-a7342591.html [accessed 20 Oct 2018]

Slegg, J. (2013), 'Google starts treating more country-code top-level domains as generic TLDs,' Search Engine Watch, 7 May. Retrieved from https://searchenginewatch. com/sew/news/2266224/google-starts-treating-more-countrycode-topleveldomains-as-generic-tlds [accessed 20 Oct 2018]

Snyder, J.; Komaitis, K. \& Robachevsky, A. (2016), 'The History of IANA,' Internet Society, 5 September. Retrieved from https://www.internetsociety.org/ ianatimeline/ [accessed 20 Oct 2018]

Stewart, W. (2000), 'Domain name system (DNS) history,' Retrieved from https:// www.livinginternet.com/i/iw_dns_history [accessed 20 Oct 2018]

The Local (2010), 'Driver's licences get expiration date,' 26 August. Retrieved from https://www.thelocal.de/20100826/29401 [accessed 20 Oct 2018]

Treaty of Lisbon (2007), Treaty of Lisbon amending the Treaty on European Union and the Treaty establishing the European Community, signed at Lisbon, 13 December 2007, OJ C 306, 17.12.2007. Retrieved from https://eur-lex.europa.eu/legalcontent/EN/TXT/?uri=celex:12007L/TXT [accessed 17 Oct 2018]

UNINETT (2017), 'Domain name policy for .no.' Retrieved from https://www.norid.no/ en/regelverk/navnepolitikk/ [accessed 20 Oct 2018] 
Verisign (2018), 'Internet Grows to 332.4 Million Domain Registrations in Q4 2017,' Verisign Domain Name Industry Brief. Retrieved from http://www.circleid.com/ posts/20180216_verisign_domain_name_industry_brief_q4_2017/[accessed 18 Oct 2018]

Walker, L. A. (2000), 'ICANN's uniform domain name dispute resolution policy,' Berkeley Technology Law Journal, vol. 15, no. 1, pp. 289-312. Retrieved from https://heinonline.org/HOL/P?h=hein.journals/berktech15\&i=299 [accessed 20 Oct 2018]

WIPO (n.d., a), 'Domain name dispute resolution service for country code top-level domains (ccTLDs), 'World Intellectual Property Organization. Retrieved from http://www.wipo.int/amc/en/domains/cctld/ [accessed 20 Oct 2018]

WIPO (n.d., b), 'How to Manage your International Registration: Renewal,' World Intellectual Property Organization. Retrieved from http://www.wipo.int/madrid/ en/how_to/manage/renewal.html [accessed 18 Oct 2018]

WIPO (n.d., c), 'IP issues related to internet domain names,' World Intellectual Property Organization. Retrieved from http://www.wipo.int/sme/en/e_commerce/domain names.htm [accessed 20 Oct 2018]

WIPO (n.d., d), 'Schedule of Fees,' World Intellectual Property Organization. Retrieved from http://www.wipo.int/amc/en/domains/fees/cctlds/index.html [accessed 17 Oct 2018]

WIPO (2018), 'ccTLD domain names ranking 2018,' World Intellectual Property Organization. Retrieved from http://www.wipo.int/amc/en/domains/statistics/ cctlds_yr.jsp?year=2018 [accessed 18 Oct 2018]

York, D. (2014), 'What is a TLD? gTLD? ccTLD? newgTLD? IDN?' Disruptive Conversations, 17 March. Retrieved from http://www.disruptiveconversations. com/2014/03/what-is-a-tld-gtld-cctld-newgtld-idn.html [accessed 20 Oct 2018]

Zimmermann, K. A. \& Emspak, J. (2017), 'Internet History Timeline: ARPANET to the World Wide Web,' Live Science. Retrieved from https://www.livescience. com/20727-internet-history.html [accessed 20 Oct 2018]

Zirnstein, E. (2005), 'Harmonization and unification of intellectual property in the EU,' Intellectual Capital and Knowledge Management, Proceedings of the 5th International Conference of the Faculty of Management Koper, University of Primorska, 18-20 November 2004, Portorož, Slovenia, pp. 293-306. Retrieved from https://repozitorij.upr.si/IzpisGradiva.php?id=1684 [accessed 18 Oct 2018] 